\title{
MODELO DE MELHORIA NO PROCESSO DE COMUNICAÇÃO EM UMA INSTITUIÇÃO FEDERAL DE ENSINO
}

\section{ARTIGO ORIGINAL}

MATOS, Fernanda de Souza Ribeiro ${ }^{1}$

MATOS, Fernanda de Souza Ribeiro. Modelo de melhoria no processo de comunicação em uma Instituição Federal De Ensino. Revista Científica Multidisciplinar Núcleo do Conhecimento. Ano 06, Ed. 01, Vol. 03, pp. 22-51. Janeiro de 2021. ISSN: 2448-0959, Link de acesso: https://www.nucleodoconhecimento.com.br/comunicacao/processo-decomunicacao

\section{RESUMO}

Este estudo apresenta o processo de comunicação como produto intrínseco das organizações. O desenvolvimento com qualidade e eficácia deste objeto trará benefícios a curto, médio e longo prazo para a cadeia estratégica das instituições. $O$ presente trabalho busca identificar - em um departamento de uma Instituição Federal de Ensino localizada na capital do Rio de Janeiro - as principais barreiras que prejudicam a comunicação organizacional no departamento, identificar a frequência do fluxo de informação no departamento junto aos colaboradores, identificar a frequência e a eficácia dos meios de comunicação utilizados, com o objetivo principal de propor um modelo com as mudanças que podem ser implementadas, a fim de, obter maior qualidade e eficácia em seu processo de comunicação organizacional interno. Para isto, seu processo metodológico desenvolveu um levantamento de informações e dados primários com uma pesquisa estruturada em 75 questões, onde os colaboradores responderam anonimamente. Questões estas, distribuídas em tópicos correlacionados com os objetivos específicos desta pesquisa. O modelo de

${ }_{1}^{1}$ Pós Graduada em Análise de Sistemas. 
resultado apresentado neste trabalho contribuirá como instrumento de pesquisa e método de tratamento de dados que pode ser utilizado em outros departamentos e instituições públicas para aprimoramento de seu processo organizacional interno.

Palavras-chave: Comunicação organizacional, barreiras à comunicação, Instituições Públicas, canais de comunicação, comunicação.

\section{INTRODUÇÃO}

Todo processo de desenvolvimento organizacional utiliza o conhecimento e o processo de comunicação organizacional interno como ferramenta base para o bom funcionamento e desempenho da instituição. Para isto, se faz necessário que o processo de comunicação e seus canais de comunicação consigam atingir seu propósito; ainda muito negligenciados por boa parte da população institucional. Entende-se "a informação sendo uma comunicação em potencial; não há possibilidade de haver comunicação sem a presença da informação, ainda que, nem toda informação seja transformada em comunicação" (BARBOUR; DOSHI; HERNANDEZ, 2016).

De acordo com Pizzaia (et al., 2019) "a comunicação organizacional acontece através dos processos comunicacionais e ciclos de informação, onde a presença deles está na evolução das estratégias empresariais e no desenvolvimento das organizações". Segundo Momo (et al., 2019) "tem se tornado cada vez mais importante a produtividade nos países".

Torna-se necessário passar pelo processo relacional porém a importância desta operação comunicacional nas organizações faz com que ela seja compreendida em um processo mais amplo e criterioso do conhecimento estratégico manifestando um empreendimento valioso por facilitar o processo comunicacional. "O eficaz andamento deste processo traz a concretização da missão e dos objetivos organizacionais" (LEE; QUEENIE, 2020). 
As organizações devem estabelecer um plano organizacional de comunicação propondo diretrizes, estratégias e orientações práticas de comunicação que possam contribuir com o crescimento econômico, social, político, acadêmico, interpessoal, e inclusive, contribuir com o auto conhecimento profissional e organizacional.

"Este plano pode ser estruturado em três eixos: pesquisa e construção de um diagnóstico estratégico da instituição; planejamento estratégico da comunicação organizacional e a gestão estratégica da comunicação" (JOHANSSON; GRANDIEN; STRANDH, 2019).

De acordo com Lima e Abbud (2015), "os modelos de comunicação organizacional estão divididos em três partes: o modelo tradicional, o modelo interpretativo e o modelo crítico".

Estes modelos identificam a comunicação organizacional sendo uma relação da comunicação com a eficiência devendo esta ser padronizada, medida e classificada para o modelo tradicional; já o modelo interpretativo tem por objetivo agregar a função da organização como cultura e espaço onde há compartilhamento de informações; e o modelo crítico trata a comunicação como instrumento de dominação dos seus colaboradores.

Este artigo tem por objetivo propor um modelo de sugestão de melhoria no processo de comunicação organizacional interno de uma Instituição Federal de Ensino localizada no Rio de Janeiro, de maneira que, busca identificar as principais barreiras que prejudicam o processo de comunicação organizacional, identificar a frequência do fluxo de informação junto aos colaboradores que atuam na repartição, identificar a frequência e a eficácia dos meios de comunicação utilizados e identificar as mudanças que podem ser implementadas, a fim de, aumentar a qualidade da comunicação organizacional. Portanto, a metodologia utilizada visa uma revisão bibliográfica dos levantamentos realizados sobre o processo de comunicação, comunicação organizacional, os canais de comunicação e as barreiras à comunicação; a elaboração e aplicação do instrumento de pesquisa (questionário) e posteriormente, o tratamento 
destes dados com o cálculo de Índice de Qualidade da Percepção do Serviço (IQPS) e por fim, as possíveis sugestões de melhoria com base nos resultados e na literatura apresentados.

\section{FUNDAMENTAÇÃO TEÓRICA}

\subsection{O PROCESSO DE COMUNICAÇÃO}

A realidade social traduz a comunicação como uma maneira simples de produzir um meio de informação. Comunicação associa-se diretamente ao conceito de comunidade não se limitando somente ao ato de se expressar mas sim uma forma de progresso social.

Portanto, por definição é "um processo de emissão e recepção utilizando canais de comunicação abarcando dois ou mais indivíduos" (SCHERMERHORN; HUNT; OSBORN, 1994).

$\mathrm{O}$ ato comunicativo se desenvolve com base em um procedimento inicial de comunicação favorecendo o crescimento humano em forma de sociedade, disseminando a inteligência, contribuindo para o crescimento organizacional.

Atos estes, que possuem uma "sequência lógica para envio da mensagem e por consequência o funcionamento do processo de comunicação" (JUNITA; ANGRAINI, 2018). Este processo foi definido com base na "Teoria da Informação publicada inicialmente por Claude Shannon em 1948" (WALKER; VENKER, 2019). Processo este que detalha os principais elementos da comunicação com base nestes autores como mostra a Tabela 1.

Tabela 1 - Elementos da comunicação com base nos autores

\begin{tabular}{|l|l|} 
Emissor & $\begin{array}{l}\text { Qualquer ser/objeto que emita mensagem de maneira consciente } \\
\text { ou não }\end{array}$
\end{tabular}




\begin{tabular}{|c|c|}
\hline Receptor & $\begin{array}{l}\text { Qualquer ser/objeto que recebe uma mensagem de forma consciente } \\
\text { ou não }\end{array}$ \\
\hline Mensagem & Informação e/ou ideia emitida e/ou recebida \\
\hline leio & $\begin{array}{l}\text { Instrumento de utilização pelo emissor/receptor para transmitir a } \\
\text { mensagem }\end{array}$ \\
\hline
\end{tabular}

Fonte: Produzido pela autora (2020)

O papel da comunicação como fator de interação entre as pessoas é reforçado pelo próprio "conceito de comunicação, derivada do latim "communicare", cujo significado é compartilhar, associar, trocar opiniões, tornar comum" (RISCHBIETER, 2015). Neste processo, conforme demonstra a Figura 1 precisa haver sintonia entre os elementos da comunicação para que esta possa ser compreendida desde o início "dando luz" ao conteúdo trafegado da informação.

Figura 1 - Processo de comunicação / ato comunicativo

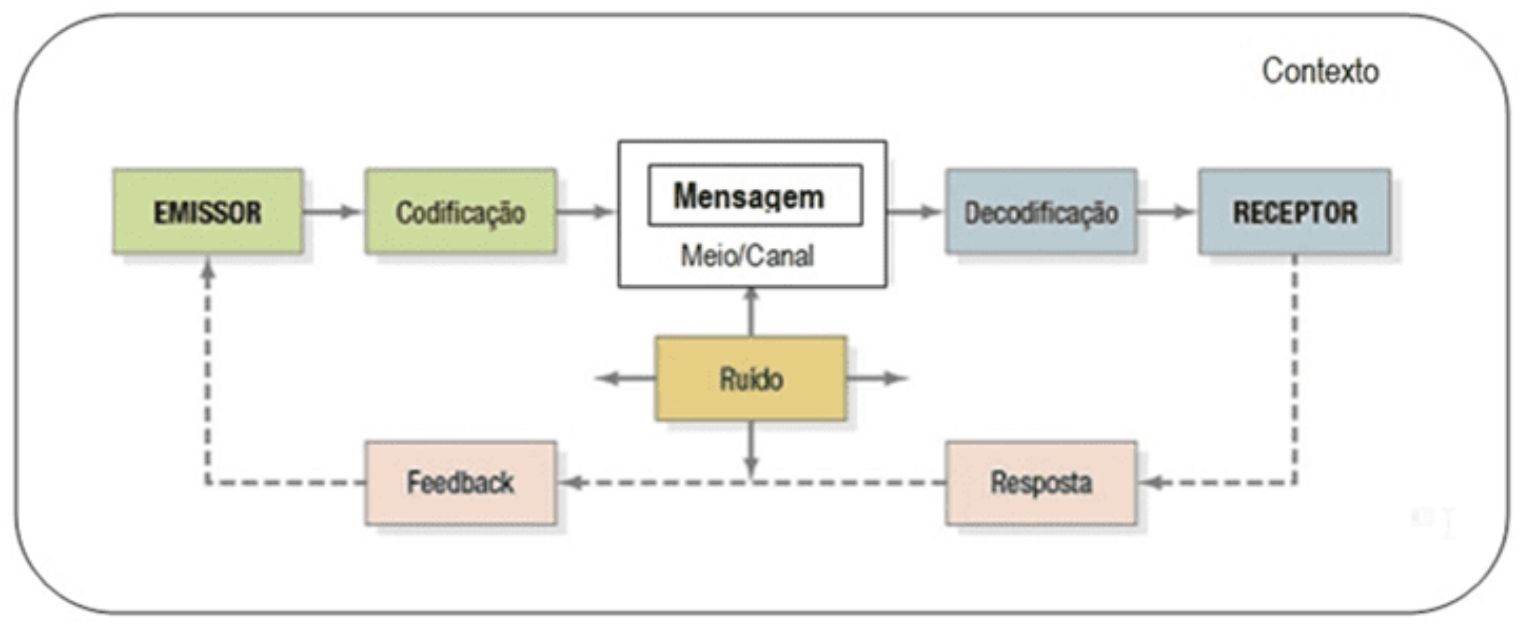

Fonte: Neves (2019)

\subsection{TIPO DE COMUNICAÇÃO INTERNA E EXTERNA}

$\mathrm{Na}$ literatura encontra-se diversos pensadores e pesquisadores de várias disciplinas como: psicologia, filosofia, sociologia, ciências humanas e linguística, que têm colaborado com possibilidades e estudos pormenorizados de cada parte de um todo

Disponível em: https://www.nucleodoconhecimento.com.br/comunicacao/processo-de- 
para a construção da "Teoria da Comunicação", uma espécie de junção de idéias que abordam a comunicação entre seres humanos. Para Araújo (2001) "fundamentado na teoria behaviorista, Lasswell (1987) entendia a ação humana como resposta a um estímulo externo", entendendo assim o meio de comunicação em massa (ou em sua abrangência).

Relata-se que, a comunicação externa realiza participação dos colaboradores gerando vantagem competitiva para a organização; a comunicação interna trata a comunicação entre os membros de uma instituição com o objetivo de melhorar o relacionamento entre os funcionários; para a comunicação de massa, tem por função informar, educar e entreter nas diferentes formas, acontece através dos canais de comunicação como: internet, redes sociais, livros, dentre outros; a comunicação pessoal tem habilidade comportamental que é aprendida e desenvolvida (natureza humana) necessita dos elementos básicos de comunicação: emissor, receptor, mensagem e meio.

\subsection{TIPO DE COMUNICAÇÃO MULTIDISCIPLINAR}

Em se tratar da comunicação em uma área multidisciplinar, seja a nível individual, grupal, organizacional, administrativo ou marketing, Robbins (2004) entende como: "característica intrínseca a transmissão de significados, valores ou atributos; gerando um canal de interesses de duas ou mais pessoas, um interesse econômico e administrativo".

Quanto a sua finalidade pode-se dizer sobre a comunicação de marketing (ou mercadologia) tendo seu foco voltado para vendas com o objetivo de divulgar produtos e serviços com finalidade comercial; a comunicação administrativa que envolve áreas de planejamento e estruturas técnico-normativas relacionadas à recursos humanos; a comunicação institucional trabalha a comunicação dos valores, missão, visão, filosofia, políticas e objetivos de uma instituição. 


\subsection{TIPO DE COMUNICAÇÃO ASCENDENTE E DESCENDENTE}

A comunicação a nível descendente, para Chiavenato (2010) significa "ter empatia e gerar um clima organizacional com informações enviadas da alta e média administração". Em um nível ascendente, Curvello (2012) destaca como "seu fluxo ocorrendo dos níveis mais baixos de uma organização aos mais altos escalões".

Visando o fluxo da comunicação diz-se que, a comunicação ascendente ocorre dos subordinados para seus superiores; a comunicação descendente tem uma estrutura de dependência hierárquica, objetivando informar, instruir e dirigir; a comunicação horizontal/lateral visa o grupo de trabalho ou entre grupos de trabalho diferentes ao mesmo nível hierárquico, visando comunicação entre as pessoas fora da cadeia de comando.

\subsection{TIPO DE COMUNICAÇÃO VERBAL E NÃO VERBAL}

Para Oliveira (2007), o tipo de comunicação verbal "tem origem na unidade da palavra, e a não verbal está ligada aos gestos, movimentos, e vários outros objetos".

Identificando quanto a forma, a comunicação verbal compreende a comunicação oral e a comunicação escrita; a comunicação não verbal trata de uma linguagem corporal ou cinésica, através de gestos, posturas, expressões faciais, ou até mesmo vestimentas; a comunicação oral é frente a frente ou à distância, através de telefone e televisão; a comunicação escrita é dita através de livros, jornais, dentre outros.

\subsection{COMUNICAÇÃO ORGANIZACIONAL}

No entorno organizacional a comunicação vem se transformando e, ao longo do tempo, ainda se adaptando à nova realidade em suas estratégias e processos internos. "Necessita ser compreendida como uma área estratégica fundamental para um desenvolvimento institucional eficiente" (JUNIOR, 2019). Apesar de ainda ser uma desafio para instituições públicas, a resistência a esta transformação faz com que o processo seja penoso e ainda retrógrado. A administração pública ainda trata a 
questão da comunicação sem importância, não compreendendo a real necessidade desse desenvolvimento, portanto torna-se imprescindível que a atualização deste torne-se um fator determinante para todo tipo de organização. "Melhorar a qualidade deste relacionamento trará benefícios a toda comunidade bem como para seus processos internos" (DUARTE, 2018).

A comunicação organizacional para Casali (2006) significa:

(...) um processo social que desencadeia mundos objetivos e subjetivos criando uma atmosfera estável e mutável. Ocorre em conversas, textos e traduções que atendem à definição de que a comunicação ocorre nas organizações e na definição subjetiva que comunica sua produção nas organizações. (CASALI, 2006)

Representa a maneira de se comunicar nas empresas e organizações em seu ambiente interno e como deve ser a interação com seu público, "garantindo a composição das dimensões de, compartilhamento vertical de mensagens (ascendente e descendente); canais (formais e informais) de comunicação e níveis hierárquicos" (NOBILE et al., 2013). Para Kunsch (2012):

(...) outras três dimensões podem ser adicionadas como: dimensão instrumental, onde há controle na produção e capacidade dos colaboradores; dimensão estratégica, onde utiliza-se as estratégias para atingir objetivos dentro de um espaço/tempo; e a dimensão humana, onde o mais importante é a que menos se tem atenção no cotidiano das organizações. (KUNSCH, 2012)

\subsection{CANAIS DE COMUNICAÇÃO}

O processo de desenvolvimento nos canais de comunicação ocorreu ao longo dos anos e associado a tecnologia estes meios vieram se adaptando, alguns destes canais diminuíram sua utilização com a grande variedade de mídias digitais contudo, uma parte ainda se mantém permanente.

Cozza e Pelotas (2019) classificam "os canais (ou ferramentas) de comunicação em quatro tipos: Audiovisuais, Auditivos, Visuais e Simbólicos". Esta classificação encontra-se devidamente esclarecida no Quadro 1 identificando sua tipologia.

Disponível em: https://www.nucleodoconhecimento.com.br/comunicacao/processo-de- 
Quadro 1 - Tipologia dos canais de comunicação

\begin{tabular}{|c|c|}
\hline Veículos Visuais Escritos & $\begin{array}{l}\text { Instruções e Ordens Escritas; } \\
\text { Circulares; } \\
\text { Cartas Pessoais; } \\
\text { Manuais; } \\
\text { Quadro de avisos (jornal mural); } \\
\text { Newsletters; } \\
\text { Boletins; } \\
\text { Panfletos; } \\
\text { Jornais e Revistas; } \\
\text { Relatórios de Atividades; } \\
\text { Formulários; } \\
\text { Fax. }\end{array}$ \\
\hline Veículos Visuais Pictográficos & $\begin{array}{l}\text { Pinturas; } \\
\text { Fotografias; } \\
\text { Desenhos; } \\
\text { Diagramas; } \\
\text { Mapas. }\end{array}$ \\
\hline Veículos Visuais Escritos/Pictográficos & Cartazes; \\
\hline
\end{tabular}




\begin{tabular}{|c|c|}
\hline & $\begin{array}{l}\text { Filmes mudos com legenda; } \\
\text { Gráficos; } \\
\text { Diplomas e certificados. }\end{array}$ \\
\hline Veículos Visuais Simbólicos & $\begin{array}{l}\text { Luzes; } \\
\text { Bandeiras e flâmulas; } \\
\text { Insígnias. }\end{array}$ \\
\hline Veículos Auditivos Diretos & $\begin{array}{l}\text { Conversas; } \\
\text { Entrevistas; } \\
\text { Reuniões; } \\
\text { Conferências; }\end{array}$ \\
\hline Veículos Auditivos Indiretos & $\begin{array}{l}\text { Telefone; } \\
\text { Rádio; } \\
\text { Intercomunicadores automáticos; } \\
\text { Alto-falantes. }\end{array}$ \\
\hline Veículos Auditivos Simbólicos & $\begin{array}{l}\text { Sirenes; } \\
\text { Apitos; } \\
\text { Buzinas; } \\
\text { Sinos; } \\
\text { Alarmes. }\end{array}$ \\
\hline Veículos Audiovisuais & Filmes utilizados em demonstrações; \\
\hline
\end{tabular}




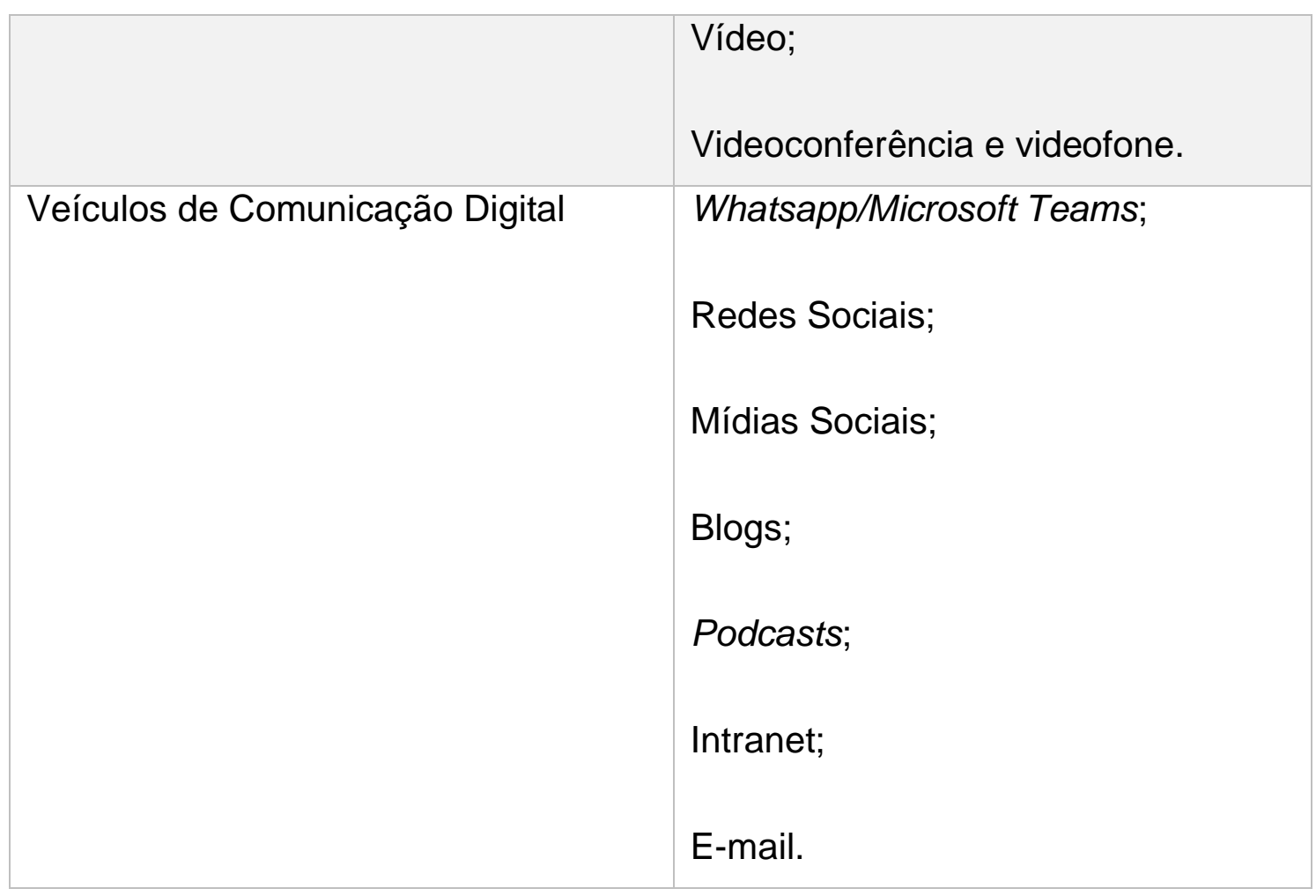

Fonte: Adaptado de Cozza e Pelotas (2019) pela autora

Estes meios permanecem no seu processo de atualização portanto cabe informar que a transmissão da informação no interior das organizações vêm se adaptando de forma gradativa através de correio eletrônico (e-mail), através de aplicativos de mensagens instantâneas (WhatsApp ou outros softwares que possuam esta função), por meio das redes sociais e a intranet para a maioria das organizações.

Em suma maioria as organizações públicas têm se utilizado destes principais meios para divulgação de informações como forma de tornar eficaz o processo de comunicação. Os meios de comunicação digital informados estão dentre os que possuem maior utilização para este processo. De acordo com a Radicati Group e seu estudo realizado entre 2016 e início de 2020 chamado E-mail Statistics Report, verificou-se que "contas ativas de correio eletrônico são utilizados em larga escala em regiões como: América do Norte, Ásia do Pacífico, Europa e o resto do mundo". 
Este estudo comprova que existem 2,6 bilhões de usuários que possuem e-mail ativo e a previsão para o final de 2020 é de que estes números subam para 3 bilhões de usuários conforme a tabela 2 a seguir.

Tabela 2 - Previsão mundial de usuários de e-mail 2016-2020

\begin{tabular}{|l|l|l|l|l|l|}
\hline & 2016 & 2017 & 2018 & 2019 & 2020 \\
\hline Usuários de E-mail Global & 2,672 & 2,760 & 2,849 & 2,943 & 3,040 \\
\hline \% Crescimento & & $3 \%$ & $3 \%$ & $3 \%$ & $3 \%$ \\
\hline
\end{tabular}

Fonte: Adaptado de Radicati Group (2018) pela Autora

Com base nestas informações entende-se que, este meio de comunicação continuará sendo utilizado em larga escala. A tendência deste estudo é identificar que o crescimento para a utilização deste canal será de $4,6 \%$ ao longo dos próximos quatro anos, fazendo dos 215,3 bilhões de e-mails enviados saltem para 257,7 bilhões até 0 final de 2020 , como mostra a tabela 3 .

Tabela 3 - Tráfego diário mundial de e-mails 2016-2020

\begin{tabular}{|l|l|l|l|l|l|}
\hline Tráfego Diário de E-mails & 2016 & 2017 & 2018 & 2019 & 2020 \\
\hline $\begin{array}{l}\text { Total de E-mails Enviados/Recebidos Global } \\
\text { (Por dia) }\end{array}$ & $\mathbf{2 1 5 , 3}$ & $\mathbf{2 2 5 , 3}$ & $\mathbf{2 3 5 , 6}$ & $\mathbf{2 4 6 , 5}$ & $\mathbf{2 5 7 , 7}$ \\
\hline \% Crescimento & & $\mathbf{4 , 6 \%}$ & $\mathbf{4 , 6 \%}$ & $\mathbf{4 , 6 \%}$ & $\mathbf{4 , 5 \%}$ \\
\hline
\end{tabular}

Fonte: Adaptado de Radicati Group (2018) pela Autora

Contudo, outros meios de comunicação atuais também muito utilizados serão destacados neste artigo, como exemplo: o aplicativo de mensagem instantânea, WhatsApp.

Em tempos atuais existem muitos aplicativos que exercem a mesma função do software mencionado, porém a utilização desta plataforma se tornou destaque ao longo dos últimos quatro anos, e por meio deste aplicativo é possível transmitir textos, 
fotos, vídeos e áudios, tornando a comunicação mais volátil. Segundo o Site Oficial do Whatsapp (2015) temos a definição para o aplicativo apresentado:

(...) WhatsApp é um aplicativo de mensagens multiplataforma que permite trocar mensagens pelo celular sem pagar por SMS. Está disponível para Iphone, Blackberry, Android, Windows Phone, e Nokia e sim, esses telefones podem trocar mensagens entre si! Como o WhatsApp Messenger usa o mesmo plano de dados de internet que você usa para e-mails e navegação, não há custo para enviar mensagens e ficar em contato com seus amigos. Além das mensagens básicas, os usuários do WhatsApp podem criar grupos, enviar mensagens ilimitadas com imagens, vídeos e áudios. (SITE OFICIAL DO WHATSAPP, 2015)

Através de uma pesquisa realizada pela Revista Digital News Report, no Brasil, o WhatsApp "tornou-se uma fonte social e organizacional de notícia de extrema importância, cerca de 55\% da população utiliza o aplicativo como meio de informação, em períodos pós pandemia essa porcentagem certamente deve ter aumentado".

Para tanto, as redes sociais vieram para contribuir ainda mais com a divulgação e transmissão em massa e rápida da informação e muitas instituições já aderiram a esta nova realidade, contudo, para Soares e Cunha (2017), "este processo ainda está lento e gradativo mas já considera-se bem aceito por boa parte dessas organizações". Assim como, a Intranet, um dos meios de comunicação utilizado em larga escala pelas organizações, e talvez o principal canal, ainda permanece em utilização. Por meio desta ferramenta é "possível divulgar as novidades da empresa, bem como, fornecer informações e treinamentos. A comunicação torna-se padronizada a todos da organização" (TURBAN; McLEAN; WETHERBE, 2004).

Este capítulo teve por objetivo identificar os principais meios de comunicação existentes em tempos atuais e sobressair os quatro tipos atualmente mais utilizados no contexto organizacional como retratado dentro dos veículos de comunicação correspondentes e pertinentes para este artigo. 


\subsection{BARREIRAS À COMUNICAÇÃO: IDENTIFICAÇÃO}

Sendo este um ponto chave deste artigo, as barreiras à comunicação representam um conjunto de situações que impossibilitam que o processo de comunicação seja eficaz. Bloqueiam a recepção correta da mensagem. É importante que haja habilidade para enfrentar as diferentes situações comunicacionais que possam ocorrer. Barreiras são limitações que acontecem entre/dentro do processo de comunicação, de maneira que, o sinal enviado percorra de forma livre buscando chegar incólume ao seu destino final. Para Chiavenato (2010) "este sinal está passível a sofrer perdas, distorções, interferências, vazamentos ou desvios no caminho". No quadro 2 identifica-se algumas destas barreiras com base em alguns autores encontrados na literatura.

Quadro 2 - Barreiras à comunicação com base em artigos pesquisados

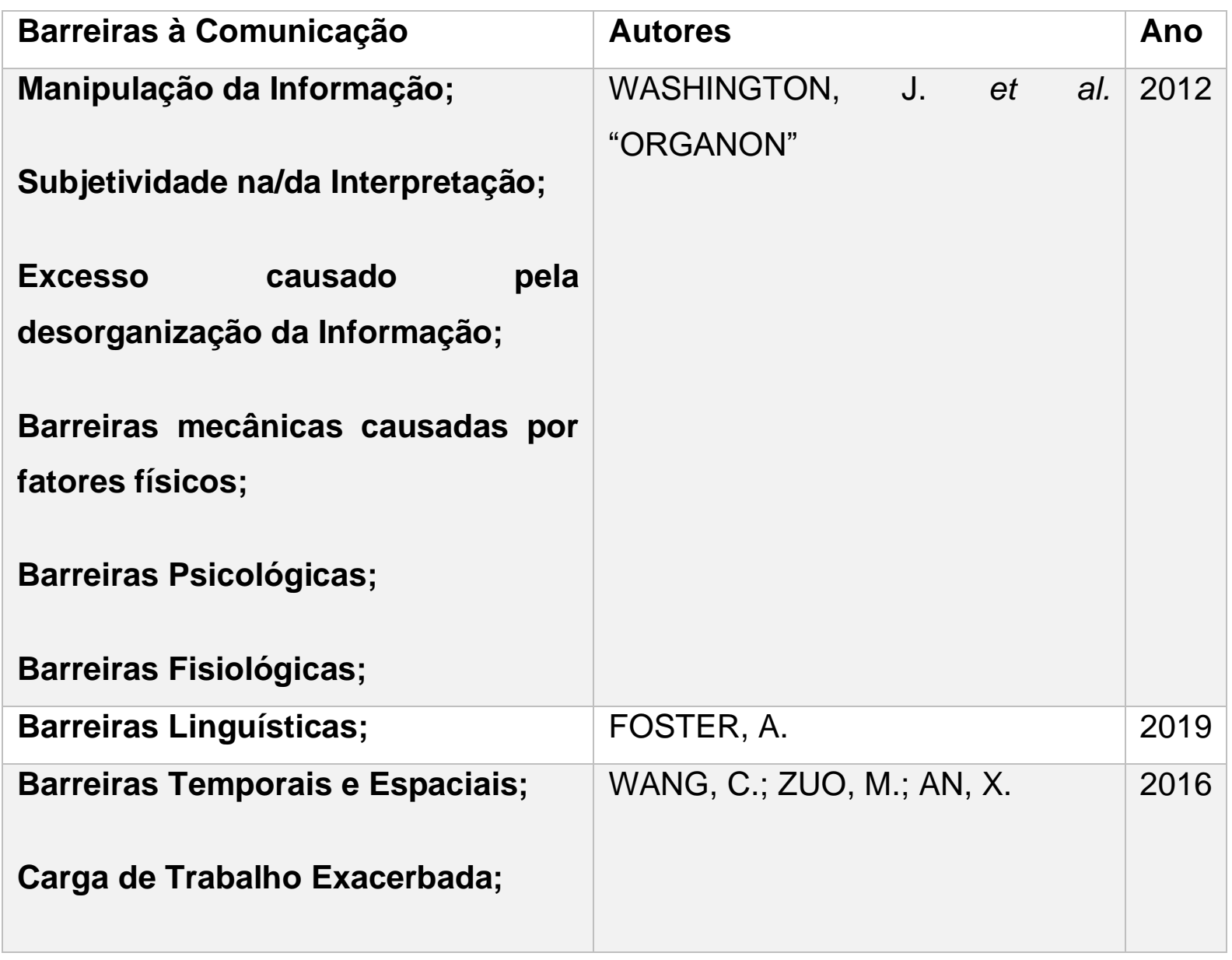




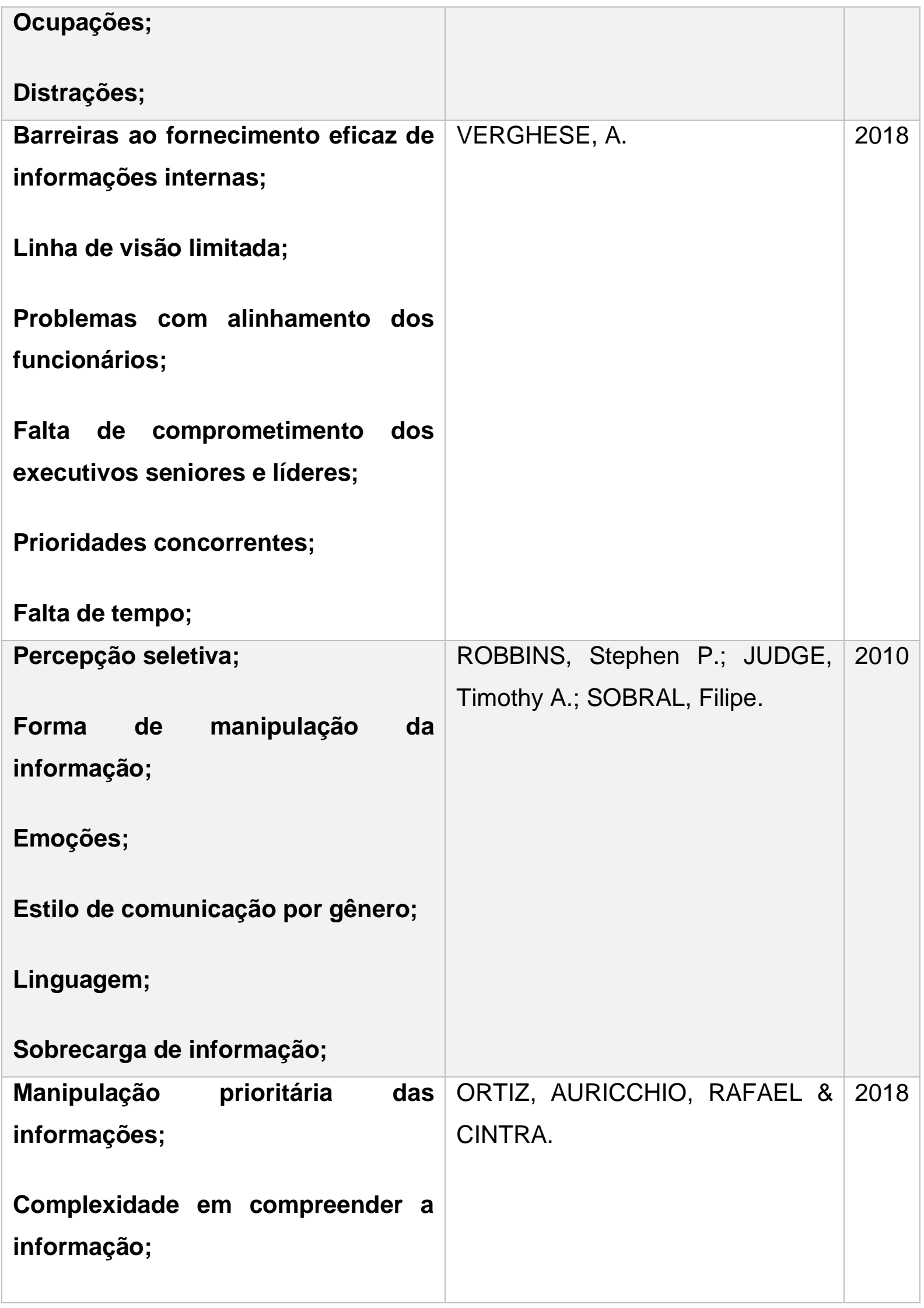




\begin{tabular}{|c|c|c|}
\hline $\begin{array}{l}\text { Complexidade na quantidade de } \\
\text { informação; }\end{array}$ & & \\
\hline $\begin{array}{l}\text { Falta de política de divulgação de } \\
\text { dados; } \\
\text { Falta de política de divulgação de } \\
\text { dados das empresas; }\end{array}$ & BASSO e DA SILVA. & 2003 \\
\hline $\begin{array}{l}\text { Percepção seletiva e afetiva; } \\
\text { Não saber ouvir; } \\
\text { Falta de confiança; } \\
\text { Juízos de valor; } \\
\text { Estereótipos e preconceitos; } \\
\text { Credibilidade da fonte; } \\
\text { Problemas semânticos; }\end{array}$ & CUNHA. & 2007 \\
\hline $\begin{array}{l}\text { Falta de clareza nas ideias; } \\
\text { Comunicação múltipla; } \\
\text { Problemas de codificação (timbre, } \\
\text { tonalidade, velocidade); } \\
\text { Bloqueio emocional; } \\
\text { Hábitos de locução; } \\
\text { Audição seletiva; } \\
\text { Desinteresse; }\end{array}$ & GIL, Antônio Carlos. & 2001 \\
\hline
\end{tabular}




\section{Avaliação prematura; \\ Preocupação com a resposta; \\ Crenças e atitudes; \\ Reação ao emissor; \\ Experiências anteriores; \\ Comportamento defensivo.}

Fonte: Produzido pela autora (2020)

Portanto, o processo de bloqueio aparece entre os emissores e os receptores e por isso existe a resistência no processo comunicacional. Estas barreiras retratam o fato de que não existe uma comunicação perfeita mas sim uma busca constante para transpô-las para que a comunicação possa ser eficaz.

\section{PROCEDIMENTOS METODOLÓGICOS}

Este capítulo descreve a metodologia adotada apresentando o detalhamento das diversas etapas realizadas para alcançar os objetivos propostos. Esta pesquisa apresenta caráter qualitativo de natureza aplicada com base na percepção de colaboradores lotados em um departamento de uma Instituição Federal de Ensino, este departamento comporta cerca de 35 funcionários para uma demanda institucional de técnico-administrativos, alunos e professores de quase vinte mil pessoas, utilizando técnicas de coleta e análise de dados adquiridos de forma experimental envolvendo uma "relação entre o objeto pesquisado e o pesquisador" (DENZIN; LINCOLN, 2006). Com base nisto, foi desenvolvido os seguintes objetivos para o atingimento de seu resultado:

1. Identificar as barreiras que prejudicam a comunicação organizacional no departamento objeto de estudo; 
2. Identificar a frequência do fluxo de informação junto aos colaboradores do departamento;

3. Identificar a frequência e a eficácia dos meios de comunicação utilizados pelos funcionários deste departamento.

E por fim, com base nesta coleta propor as possíveis mudanças que possam ser implementadas para aumentar a qualidade e a eficácia da comunicação organizacional interna. Este estudo abrangeu a realização das seguintes etapas: 1 Pesquisa Bibliográfica; 2- Pesquisa Documental; 3- Elaboração do Instrumento de Pesquisa (Questionário); 4- Aplicação do Questionário; 5- Identificação e Hierarquização das Barreiras; 6- Identificação da eficiência do Fluxo de Informação; 7- Identificação da eficiência e eficácia dos meios e/ou canais de comunicação utilizados; e 8- Identificação das mudanças a serem implementadas.

Para a pesquisa bibliográfica utilizou-se fatos encontrados na literatura com o objetivo de subsidiar a fundamentação teórica, o processo de comunicação, a comunicação organizacional, os canais de comunicação e as barreiras à comunicação. A pesquisa documental envolveu o levantamento de documentos da Instituição Federal de Ensino - objeto deste estudo - a fim de obter informações capazes de melhor caracterizar a unidade de análise. Para a elaboração do questionário, realizou uma seleção de perguntas retiradas de outras instituições públicas como IFSP (Instituto Federal de Educação, Ciência e Tecnologia de São Paulo), a QUESCI UFP, UNESC, EMASA e EMBRAPA para adquirir dados primários referentes ao estudo sob os diversos aspectos referentes à comunicação organizacional; foi aplicado a um grupo de pessoas das quais se deseja obter estas informações. Deste questionário foram elaboradas 75 questões distribuídas em tópicos de interesse para um grupo de colaboradores do departamento objeto de estudo referente a dados pessoais e profissionais do perfil do respondente, questões sobre as barreiras que atuam dificultando o processo de comunicação organizacional; identificar a frequência do fluxo de informação com que estes colaboradores se relacionam; identificar a frequência e eficácia da utilização dos diversos canais de comunicação e as possíveis mudanças que poderiam ocorrer para uma eficaz comunicação. Foram perguntas 
realizadas com escalas variando de "concordo totalmente" até "discordo totalmente"; ou "muita frequência" até "nunca"; ou "muita eficácia" até "nenhuma eficácia", de acordo com cada questionamento. Sua aplicação se deu através da plataforma Google Forms visando seu preenchimento de forma online, foi utilizado este método pois esta pesquisa foi realizada em um momento atípico vivido pela pandemia global - COVID-19.

Para identificar a hierarquização das principais barreiras que dificultam o processo comunicacional foi utilizado o Índice de Qualidade Percebida no Serviço (IQPS).

O índice IQPS é calculado com base na frequência relativa de respostas obtidas para cada pergunta do questionário, podendo variar de 0 (zero) até 1 (um) e, quanto mais próximo de 1, maior a qualidade percebida como mostra a tabela 4.

Tabela 4 - Cálculo IQPS

\begin{tabular}{|l|l|l|l|l|}
\hline Resposta & $\mathbf{f}$ & $\%$ & $\%(\mathbf{v d})$ & IQPS \\
\hline Concordo Totalmente & 39 & 25,33 & 0,25 & 0,54 \\
\hline Concordo & 45 & 29,22 & 0,29 & \\
\hline Concordo medianamente & 42 & 27,27 & 0,27 & \\
\cline { 1 - 4 } Discordo & 18 & 11,69 & 0,12 & \\
\hline Discordo Totalmente & 10 & 6,49 & 0,07 & \\
Total & 154 & 100 & 1 & \\
\hline
\end{tabular}

Fonte: Oliveira (2008)

Conforme observado, o IQPS é de 0,54, correspondendo ao somatório da frequência relativa das respostas Concordo Totalmente $(0,25)$ e Concordo $(0,29)$. Se o IQPS for maior que 0,5 significa que mais da metade dos respondentes avaliou positivamente aquele índice e é considerado satisfatório. Por exemplo, uma pergunta como: "as informações são repassadas de forma clara e objetiva?", é desejável um IQPS alto, ou seja, que ele esteja perto de 1,0. Este estudo optou por utilizar esta opção. 
Para identificação da frequência do fluxo de comunicação, esta etapa consistiu na tabulação e análise das respostas obtidas a partir do questionário. $\mathrm{Na}$ fase de identificação da frequência e eficácia dos meios de comunicação utilizados buscou-se fazer uso de estatística descritiva para apresentação dos resultados. E por fim, na etapa de identificação das mudanças foi realizada uma estatística descritiva para identificação das percepções dos colaboradores visando promover a melhoria no processo de comunicação organizacional.

Quadro 3 - Questionário de pesquisa

Roteiro de Entrevista

Perfil Profissional e Sócio Demográfico

1) Sexo

2) Idade

3) Quantos anos de serviço possui na instituição?

4) Qual setor você trabalha no departamento?

5) Maior formação acadêmica?

6) Ocupa cargo de chefia?

7) Em sua opinião, o quadro de colaboradores do setor comporta a quantidade de demanda?

Comunicação Organizacional Interna

Em uma escala variando de "Concordo Totalmente" até "Discordo Totalmente", qual a sua percepção em relação às afirmativas? 
8) Os colaboradores possuem conhecimento sobre as atribuições, objetivos e metas do departamento.

9) As informações são amplamente divulgadas dentro do setor.

10) Os colaboradores conhecem bem suas atribuições e responsabilidades.

11) Os colaboradores são capacitados e recebem treinamentos adequados para a realização de suas atividades.

12) Os colaboradores recebem orientações e informações necessárias e suficientes para a realização do seu trabalho.

13) As informações são repassadas com antecedência necessária para que todos tomem ciência em tempo hábil.

14) As informações são passadas de forma clara e objetiva dentro do setor.

15) Os meios de comunicação utilizados para repassar as informações são adequados.

16) Os colaboradores recebem feedback em relação ao trabalho realizado.

17) Os colaboradores do departamento procuram manter-se informados lendo os comunicados e documentos repassados.

18) Os colaboradores são comprometidos com o trabalho e a realização das atividades.

19) A comunicação entre chefia e subordinado é rápida e existe fácil acesso aos superiores.

20) A comunicação interna entre colaboradores é rápida e existe fácil acesso aos colegas de trabalho. 
21) O clima organizacional favorece a comunicação dentro do departamento.

22) Os colaboradores têm liberdade e são estimulados a darem opiniões sobre as questões do trabalho.

23) A opinião e posicionamento dos colaboradores são levados em consideração pelas chefias.

24) O processo de comunicação interno é muito centralizado.

25) O tempo de resposta é longo e prejudica a comunicação organizacional interna.

26) De modo geral, a comunicação no setor é eficaz.

Em relação aos problemas enfrentados, em uma escala variando de "Concordo Totalmente" até "Discordo Totalmente", qual a sua percepção?

27) Problemas de relacionamento entre os colaboradores e as chefias prejudicam a comunicação interna dentro do departamento.

28) Problemas relacionados à infraestrutura (falta de equipamentos, sistemas, falhas de conexão, entre outros) prejudicam a comunicação no setor.

29) Problemas de relacionamento entre os colaboradores prejudicam a comunicação interna no departamento.

30) Existe sobrecarga de trabalho que prejudica a comunicação interna do setor.

31) Existe excesso de informação que prejudica a comunicação interna e a realização das atividades. 
32) Ocorrem orientações divergentes/conflitos de prioridades em relação ao trabalho que prejudicam a realização das atividades.

33) Existem aspectos de natureza psicológica (falta de confiança, receios, desmotivação) que afetam a comunicação interna do departamento.

34) Problemas no processo de comunicação são muito burocráticos prejudicando o fluxo e a troca de informações de forma rápida e eficaz.

35) Existe comunicação e troca de informações, de maneira informal, entre os colaboradores do departamento que contribui para a realização das atividades.

Em uma escala variando de "Muita Frequência" até "Nunca" com que frequência você troca informações com as seguintes pessoas no exercício de suas atividades relacionadas ao setor?

36) Chefia imediata.

37) Colegas dentro do meu setor.

38) Colegas de outros setores.

39) Colegas de outros setores da capital.

40) Colegas de outros campi.

41) Alunos.

42) Público Externo.

Em uma escala variando de "Muita Frequência" até "Nunca" com que frequência você utiliza os seguintes meios/canais de comunicação para obter 
informações e tirar dúvidas relacionadas às suas atividades no departamento?

43) Memorandos/Ofícios.

44) Página Institucional.

45) E-mail

46) Aplicativos de mensagem instantânea (WhatsApp/Microsoft teams).

47) Mídias sociais.

48) Telefone.

49) Sistema de chamados.

50) Quadro de avisos.

51) Reunião de trabalho.

52) Conversa com colegas.

53) Conversa com a chefia.

Em uma escala variando de "Muito Eficaz" até "Não Eficaz" qual o nível de eficácia que você atribui para cada um dos seguintes meios de comunicação para obtenção de orientações e informações ao trabalho no setor?

54) Memorandos/Ofícios.

55) Página Institucional.

56) E-mail 
57) Aplicativos de mensagem instantânea (WhatsApp/Microsoft teams).

58) Mídias sociais.

59) Telefone.

60) Sistema de chamados.

61) Quadro de avisos.

62) Reunião de trabalho.

63) Conversa com colegas.

64) Conversa com a chefia.

Em uma escala variando de "Muito Importante" até "Sem Importância" como você avalia a necessidade de promover as seguintes mudanças para a melhoria na comunicação interna no departamento?

65) Revisão dos fluxos e processos para melhorar a comunicação interna no departamento.

66) Elaboração de novos documentos ou revisão dos manuais existentes com descrição de procedimentos e orientações sobre o trabalho.

67) Maior divulgação de informações.

68) Maior quantidade de reuniões.

69) Diminuição da burocracia.

70) Realização de seminários internos para compartilhamento de informações. 
71) Ampliação do processo participativo para tomada de decisões.

72) Melhoria do clima organizacional e das relações interpessoais entre os funcionários e chefia.

73) Mudança dos canais de comunicação utilizados para passar informações.

74) Aponte outras sugestões que poderiam contribuir para melhorar a comunicação organizacional interna do departamento.

75) Caso tenha algum comentário adicional em relação à comunicação organizacional do setor, por favor deixe registrado.

Fonte: Produzido pela autora (2020)

\section{RESULTADOS}

O referido estudo procurou obter dados de uma unidade de análise de um departamento de uma Instituição Federal de Ensino localizada na cidade do Rio de Janeiro e detentora de outros campos espalhados por seu município que tem sua origem nos anos de 1917. Compreende um espaço público para qualificação científico-tecnológica e integra cursos de ensino técnico de nível médio, ensino técnico subsequente, ensino tecnológico de nível superior, graduação e pós-graduação lato e stricto sensu (mestrado e doutorado) com a missão de "promover educação mediante atividades de ensino, pesquisa e extensão que propiciem, de modo reflexivo e crítico a formação integral de profissionais capazes de contribuir para o desenvolvimento científico, cultural, tecnológico e econômico da sociedade."

O resultado desta aplicação teve um retorno de 20 respostas suficientes para análise deste estudo. Como verifica-se na tabela 5 foi executado o cálculo IQPS para as barreiras existentes no departamento, com o fator de indicação (+) para questões em que o IQPS deve ser alto e a indicação (-) para questões em que deve ser baixo para 
caracterizar um bom resultado. A tabela indica se o resultado pode ser satisfatório (S) ou insatisfatório (I). Em questões com indicação (+), foi considerado satisfatório com um IQPS maior que 0,5 , e nas questões com indicação (-), foi considerado satisfatório com um IQPS com indicação menor que 0,5 . Para maior esclarecimento às siglas na tabela indicam "CT" para concordo totalmente, "C" para concordo, "CM" para concordo medianamente, "D" para discordo, "DT" para discordo totalmente e "NS" para não sei/prefiro não responder.

Tabela 5 - Questionário IQPS

\begin{tabular}{|c|c|c|c|c|c|c|c|c|c|}
\hline Fator Considerado & CT & C & CM & D & DT & NS & +1 & $\begin{array}{l}\text { IQP } \\
S\end{array}$ & $\begin{array}{l}\text { Situaçã } \\
0\end{array}$ \\
\hline $\begin{array}{lr}\text { Conhecimento } & \text { das } \\
\text { atribuições } & \text { do } \\
\text { departamento } & \end{array}$ & $\begin{array}{l}0,1 \\
0\end{array}$ & $\begin{array}{l}0,3 \\
5\end{array}$ & $\begin{array}{l}0,4 \\
5\end{array}$ & $\begin{array}{l}0,1 \\
0\end{array}$ & 0 & 0 & + & 0,45 & 1 \\
\hline $\begin{array}{ll}\text { Divulgação } & \text { de } \\
\text { informações } & \end{array}$ & $\begin{array}{l}0,1 \\
0\end{array}$ & $\begin{array}{l}0,1 \\
5\end{array}$ & $\begin{array}{l}0,4 \\
0\end{array}$ & $\begin{array}{l}0,2 \\
5\end{array}$ & $\begin{array}{l}0,1 \\
0\end{array}$ & 0 & + & 0,25 & 1 \\
\hline $\begin{array}{l}\text { Conhecimento de suas } \\
\text { atribuições/responsabili } \\
\text { dade }\end{array}$ & $\begin{array}{l}0,3 \\
0\end{array}$ & $\begin{array}{l}0,4 \\
0\end{array}$ & $\begin{array}{l}0,2 \\
5\end{array}$ & 0 & $\begin{array}{l}0,0 \\
5\end{array}$ & 0 & + & 0,70 & $S$ \\
\hline $\begin{array}{l}\text { Capacitação } \\
\text { treinamento }\end{array}$ & $\begin{array}{l}0,1 \\
5\end{array}$ & $\begin{array}{l}0,1 \\
5\end{array}$ & $\begin{array}{l}0,3 \\
0\end{array}$ & $\begin{array}{l}0,2 \\
0\end{array}$ & $\begin{array}{l}0,1 \\
5\end{array}$ & $\begin{array}{l}0,0 \\
5\end{array}$ & + & 0,30 & 1 \\
\hline $\begin{array}{l}\text { Orientações e } \\
\text { informações suficientes }\end{array}$ & $\begin{array}{l}0,1 \\
5\end{array}$ & $\begin{array}{l}0,2 \\
0\end{array}$ & $\begin{array}{l}0,4 \\
5\end{array}$ & $\begin{array}{l}0,2 \\
0\end{array}$ & 0 & 0 & + & 0,35 & 1 \\
\hline $\begin{array}{l}\text { Informações } \quad \text { com } \\
\text { antecedência }\end{array}$ & $\begin{array}{l}0,0 \\
5\end{array}$ & $\begin{array}{l}0,1 \\
5\end{array}$ & & $\begin{array}{l}0,3 \\
0\end{array}$ & $\begin{array}{l}0,1 \\
0\end{array}$ & $\begin{array}{l}0,0 \\
5\end{array}$ & + & 0,20 & 1 \\
\hline $\begin{array}{l}\text { Informações claras e } \\
\text { objetivas }\end{array}$ & $\begin{array}{l}0,0 \\
5\end{array}$ & $\begin{array}{l}0,4 \\
0\end{array}$ & $\begin{array}{l}0,3 \\
5\end{array}$ & $\begin{array}{l}0,1 \\
0\end{array}$ & $\begin{array}{l}0,1 \\
0\end{array}$ & 0 & + & 0,45 & 1 \\
\hline $\begin{array}{l}\text { Meios de comunicação } \\
\text { adequados }\end{array}$ & $\begin{array}{l}0,1 \\
5\end{array}$ & $\begin{array}{l}0,5 \\
5\end{array}$ & $\begin{array}{l}0,2 \\
0\end{array}$ & $\begin{array}{l}0,1 \\
0\end{array}$ & 0 & 0 & + & 0,70 & $S$ \\
\hline
\end{tabular}




\begin{tabular}{|c|c|c|c|c|c|c|c|c|c|}
\hline Feedback do trabalho & $\begin{array}{l}0,1 \\
0\end{array}$ & $\begin{array}{l}0,3 \\
5\end{array}$ & $\begin{array}{l}0,4 \\
0\end{array}$ & $\begin{array}{l}0,1 \\
5\end{array}$ & 0 & 0 & + & 0,45 & 1 \\
\hline $\begin{array}{l}\text { Funcionários buscam } \\
\text { manter-se informados }\end{array}$ & $\begin{array}{l}0,1 \\
0\end{array}$ & $\begin{array}{l}0,2 \\
0\end{array}$ & $\begin{array}{l}0,4 \\
0\end{array}$ & $\begin{array}{l}0,1 \\
5\end{array}$ & $\begin{array}{l}0,0 \\
5\end{array}$ & $\begin{array}{l}0,1 \\
0\end{array}$ & + & 0,30 & 1 \\
\hline $\begin{array}{l}\text { Funcionários } \quad \text { são } \\
\text { comprometidos }\end{array}$ & $\begin{array}{l}0,3 \\
5\end{array}$ & $\begin{array}{l}0,4 \\
0\end{array}$ & $\begin{array}{l}0,1 \\
5\end{array}$ & $\begin{array}{l}0,1 \\
0\end{array}$ & 0 & 0 & + & 0,75 & $\mathrm{~s}$ \\
\hline $\begin{array}{l}\text { Comunicação com chefia } \\
\text { rápida e acessível }\end{array}$ & $\begin{array}{l}0,4 \\
5\end{array}$ & $\begin{array}{l}0,4 \\
0\end{array}$ & $\begin{array}{l}0,1 \\
0\end{array}$ & $\begin{array}{l}0,0 \\
5\end{array}$ & 0 & 0 & + & 0,85 & $\mathrm{~S}$ \\
\hline $\begin{array}{l}\text { Comunicação entre } \\
\text { pares rápida e acessível }\end{array}$ & $\begin{array}{l}0,4 \\
5\end{array}$ & $\begin{array}{l}0,3 \\
5\end{array}$ & $\begin{array}{l}0,1 \\
0\end{array}$ & $\begin{array}{l}0,1 \\
0\end{array}$ & 0 & 0 & + & 0,80 & $\mathrm{~S}$ \\
\hline $\begin{array}{l}\text { Clima organizacional } \\
\text { favorece comunicação }\end{array}$ & $\begin{array}{l}0,2 \\
0\end{array}$ & $\begin{array}{l}0,5 \\
5\end{array}$ & $\begin{array}{l}0,2 \\
0\end{array}$ & $\begin{array}{l}0,0 \\
5\end{array}$ & 0 & 0 & + & 0,75 & $\mathrm{~S}$ \\
\hline $\begin{array}{l}\text { Funcionários } \\
\text { estimulados a opinarem }\end{array}$ & $\begin{array}{l}0,4 \\
5\end{array}$ & $\begin{array}{l}0,3 \\
0\end{array}$ & $\begin{array}{l}0,2 \\
0\end{array}$ & $\begin{array}{l}0,0 \\
5\end{array}$ & 0 & 0 & + & 0,75 & $\mathrm{~s}$ \\
\hline $\begin{array}{l}\text { Opinião dos funcionários } \\
\text { consideradas pelas } \\
\text { chefias }\end{array}$ & $\begin{array}{l}0,4 \\
0\end{array}$ & $\begin{array}{l}0,3 \\
5\end{array}$ & $\begin{array}{l}0,1 \\
0\end{array}$ & $\begin{array}{l}0,1 \\
0\end{array}$ & $\begin{array}{l}0,0 \\
5\end{array}$ & 0 & + & 0,75 & $\mathrm{~s}$ \\
\hline $\begin{array}{l}\text { Processo } \\
\text { comunicação } \\
\text { centralizado }\end{array}$ & $\begin{array}{l}0,0 \\
5\end{array}$ & $\begin{array}{l}0,1 \\
0\end{array}$ & $\begin{array}{l}0,3 \\
5\end{array}$ & $\begin{array}{l}0,3 \\
5\end{array}$ & $\begin{array}{l}0,1 \\
0\end{array}$ & $\begin{array}{l}0,0 \\
5\end{array}$ & - & 0,15 & $\mathrm{~S}$ \\
\hline $\begin{array}{l}\text { Tempo de resposta } \\
\text { longo }\end{array}$ & $\begin{array}{l}0,0 \\
5\end{array}$ & $\begin{array}{l}0,0 \\
5\end{array}$ & & & $\begin{array}{l}0,1 \\
5\end{array}$ & $\begin{array}{l}0,0 \\
5\end{array}$ & - & 0,10 & $S$ \\
\hline Comunicação é eficaz & $\begin{array}{l}0,1 \\
6\end{array}$ & $\begin{array}{l}0,4 \\
7\end{array}$ & $\begin{array}{l}0,1 \\
6\end{array}$ & & $\begin{array}{l}0,0 \\
5\end{array}$ & 0 & + & 0,63 & $\mathrm{~s}$ \\
\hline $\begin{array}{l}\text { Problemas } \\
\text { relacionamento entre } \\
\text { colaboradores e chefia }\end{array}$ & $\begin{array}{l}0,1 \\
5\end{array}$ & $\begin{array}{l}0,2 \\
0\end{array}$ & $\begin{array}{l}0,2 \\
5\end{array}$ & $\begin{array}{l}0,3 \\
5\end{array}$ & $\begin{array}{l}0,0 \\
5\end{array}$ & 0 & - & 0,35 & $\mathrm{~S}$ \\
\hline $\begin{array}{ll}\text { Problemas } & \text { de } \\
\text { infraestrutura } & \end{array}$ & $\begin{array}{l}0,0 \\
5\end{array}$ & $\begin{array}{l}0,2 \\
0\end{array}$ & $\begin{array}{l}0,5 \\
5\end{array}$ & $\begin{array}{l}0,2 \\
0\end{array}$ & 0 & 0 & - & 0,25 & $\mathrm{~s}$ \\
\hline
\end{tabular}




\begin{tabular}{|c|c|c|c|c|c|c|c|c|c|}
\hline $\begin{array}{l}\text { Problemas } \\
\text { relacionamento entre } \\
\text { colaboradores }\end{array}$ & $\begin{array}{l}0,1 \\
1\end{array}$ & $\begin{array}{l}0,2 \\
6\end{array}$ & $\begin{array}{l}0,1 \\
1\end{array}$ & $\begin{array}{l}0,4 \\
2\end{array}$ & $\begin{array}{l}0,0 \\
5\end{array}$ & $\begin{array}{l}0,0 \\
5\end{array}$ & - & 0,37 & $S$ \\
\hline Sobrecarga de trabalho & $\begin{array}{l}0,1 \\
0\end{array}$ & $\begin{array}{l}0,2 \\
5\end{array}$ & $\begin{array}{l}0,2 \\
5\end{array}$ & $\begin{array}{l}0,2 \\
0\end{array}$ & $\begin{array}{l}0,1 \\
0\end{array}$ & $\begin{array}{l}0,1 \\
0\end{array}$ & - & 0,35 & $S$ \\
\hline Excesso de informação & $\begin{array}{l}0,0 \\
5\end{array}$ & $\begin{array}{l}0,1 \\
5\end{array}$ & $\begin{array}{l}0,3 \\
0\end{array}$ & $\begin{array}{l}0,2 \\
0\end{array}$ & $\begin{array}{l}0,2 \\
0\end{array}$ & $\begin{array}{l}0,1 \\
0\end{array}$ & - & 0,20 & $S$ \\
\hline $\begin{array}{l}\text { Orientações divergentes } \\
\text { e conflitos de prioridade }\end{array}$ & $\begin{array}{l}0,2 \\
0\end{array}$ & $\begin{array}{l}0,2 \\
5\end{array}$ & $\begin{array}{l}0,2 \\
0\end{array}$ & $\begin{array}{l}0,1 \\
5\end{array}$ & $\begin{array}{l}0,1 \\
0\end{array}$ & $\begin{array}{l}0,1 \\
0\end{array}$ & - & 0,45 & $S$ \\
\hline $\begin{array}{l}\text { Problemas de natureza } \\
\text { psicológica }\end{array}$ & $\begin{array}{l}0,1 \\
5\end{array}$ & $\begin{array}{l}0,3 \\
0\end{array}$ & $\begin{array}{l}0,2 \\
0\end{array}$ & $\begin{array}{l}0,1 \\
0\end{array}$ & & $\begin{array}{l}0,0 \\
5\end{array}$ & - & 0,45 & $S$ \\
\hline $\begin{array}{l}\text { Problemas no processo } \\
\text { de comunicação } \\
\text { burocrática }\end{array}$ & $\begin{array}{l}0,0 \\
5\end{array}$ & $\begin{array}{l}0,1 \\
0\end{array}$ & $\begin{array}{l}0,2 \\
0\end{array}$ & $\begin{array}{l}0,4 \\
0\end{array}$ & & & - & 0,15 & $S$ \\
\hline $\begin{array}{l}\text { Comunicação e troca de } \\
\text { informação informal }\end{array}$ & $\begin{array}{l}0,3 \\
5\end{array}$ & $\begin{array}{l}0,5 \\
5\end{array}$ & $\begin{array}{l}0,0 \\
5\end{array}$ & 0 & 0 & & + & 0,90 & S \\
\hline $\begin{array}{l}\text { Posicionamento } \\
\text { funcionários em relação } \\
\text { à chefia }\end{array}$ & $\begin{array}{l}0,4 \\
0\end{array}$ & $\begin{array}{l}0,3 \\
5\end{array}$ & $\begin{array}{l}0,1 \\
0\end{array}$ & $\begin{array}{l}0,1 \\
0\end{array}$ & $\begin{array}{l}0,0 \\
5\end{array}$ & 0 & + & 0,75 & $S$ \\
\hline
\end{tabular}

Fonte: Produzido pela autora (2020)

Conforme observado, o questionário apontou 8 (oito) itens com resultado insatisfatório: 1 - conhecimento das atribuições do departamento, 2 - divulgação de informações, 3 - capacitação e treinamento, 4 - falta de orientação e informações suficientes, 5 - falta de informações com antecedência, 6 - falta de informações claras e objetivas, 7 - falta de feedback em relação ao trabalho, 8 - funcionários não buscam manter-se atualizados. Os quais, serão propostas as respectivas melhorias.

Contudo, além do questionário, foi sugerido aos colaboradores que apontassem outras sugestões que poderiam contribuir para melhorar o processo de comunicação organizacional interno e estas respostas estão citadas abaixo: 
Quadro 4 - Quadro de sugestões

\section{Sugestão dos colaboradores}

“Menos burocracia para a divulgação de informações públicas” - Anônimo.

"As pessoas se relacionam mais. Ainda vejo colegas que poderiam se relacionar melhor" - Anônimo.

"Não sei. Talvez um rodízio dos funcionários para que se conheçam melhor e conheçam os demais setores, suas idiossincrasias" - Anônimo.

"Definir as atribuições e cada um dos membros da equipe de cada setor podendo inclusive cada tarefa ser de responsabilidade de mais de um membro da equipe" - Anônimo.

"Elaboração de um calendário de reuniões curtas para nivelamento de informações" - Anônimo.

“Mudança profunda de cultura. Mais transparência técnica, menos política” Anônimo.

"Usar apenas as ferramentas institucionais" - Anônimo.

"Acredito que as informações também poderiam nos ser passadas de fora para dentro do departamento" - Anônimo.

"Ampliação do uso de comunicadores instantâneos (Microsoft teams), resumos individuais nas reuniões das atividades desenvolvidas" - Anônimo.

Fonte: Produzido pela autora (2020)

$\mathrm{E}$, três destes participantes responderam a última pergunta referente a algum comentário adicional que poderia ser feito em relação à comunicação organizacional dentro do departamento, seguem estas respostas:

Quadro 5 - Comentários adicionais

Comentários adicionais

"Que os colegas de trabalho, sejam mais comunicativos, temos alguns colegas, que é difícil até um Bom Dia!” - Anônimo. 
"Mudança profunda de cultura. Mais transparência técnica, menos política" Anônimo.

"As más relações interpessoais (algumas vezes entre chefe e chefiado e outras entre membros da mesma equipe e a questão hierárquica de membros da equipe) muitas vezes podem minar o relacionamento e atrapalhar o fluxo de comunicação, da informação e do trabalho" - Anônimo.

Fonte: Produzido pela autora (2020)

Para confirmar estas respostas, a tabela 6 informa o que os respondentes consideram ser mais importante para que ocorram as devidas mudanças segundo o resultado do instrumento de pesquisa deste artigo.

Tabela 6 - Mudanças entendidas como importantes

\begin{tabular}{|l|l|}
\hline Necessidade de mudanças & $\%$ \\
nudanças nos fluxos e processidade \\
\hline $\begin{array}{l}\text { comunicação. } \\
\text { Mudanças para uma maior divulgação da informação. }\end{array}$ & $90 \%$ \\
\hline $\begin{array}{l}\text { Mudanças na elaboração de novos documentos ou da } \\
\text { revisão de manuais. }\end{array}$ & $80 \%$ \\
\hline $\begin{array}{l}\text { Mais frequência de seminários para compartilhar } \\
\text { informações. }\end{array}$ & $80 \%$ \\
\hline $\begin{array}{l}\text { Mudanças no clima organizacional e relações } \\
\text { interpessoais }\end{array}$ & $80 \%$ \\
\hline $\begin{array}{l}\text { Ampliação do processo participativo para tomada de } \\
\text { decisão }\end{array}$ & $75 \%$ \\
\hline \begin{tabular}{l} 
Mudanças para diminuir a burocracia. \\
\hline
\end{tabular} & $60 \%$ \\
\hline
\end{tabular}

Fonte: Produzido pela Autora (2020) 
Contudo, além deste levantamento, foram identificados que os meios de comunicação apontados como mais frequentes para obter informações e tirar dúvidas em relação às atividades no departamento estão identificados na tabela 7 .

Tabela 7 - Canais de Comunicação mais Utilizados

\begin{tabular}{|l|l|}
\hline Canais/Meios de Comunicação & $\%$ de Frequência de Utilização \\
\hline E-mail & $100 \%$ \\
\hline Conversa com Colegas & $95 \%$ \\
\hline Conversa com Chefia & $90 \%$ \\
\hline Reunião de Trabalho & $85 \%$ \\
\hline Whatsapp/Microsoft Teams & $85 \%$ \\
\hline Sistema de Chamados & $75 \%$ \\
\hline
\end{tabular}

Fonte: Produzido pela autora (2020)

Nota-se que, a utilização destes canais de comunicação não indica a sua eficiência, pois, para isto, verificou-se quais seriam os canais de comunicação mais eficazes para obter informação e orientação referente ao trabalho executado no departamento conforme apresentado na tabela 8.

Tabela 8 - Meios de Comunicação Eficazes

\begin{tabular}{|l|l|}
\hline Meio de Comunicação & $\%$ de Eficácia \\
\hline Conversa com Chefia & $95 \%$ \\
\hline E-mail & $95 \%$ \\
\hline Whatsapp/Microsoft teams & $95 \%$ \\
\hline Sistema de Chamados & $95 \%$ \\
\hline Reunião de Trabalho & $95 \%$ \\
\hline Conversa com Colegas & $90 \%$ \\
\hline Página Institucional & $60 \%$ \\
\hline
\end{tabular}

Fonte: Produzido pela autora (2020) 
Estes resultados retratam a percepção dos colaboradores até o momento desta pesquisa, lembrando que, a mesma foi realizada em um momento atípico vivido pela sociedade. Portanto, em meados de uma pandemia global, a COVID-19, estes resultados sofreram alteração, tanto em forma de cultura como na forma de se comunicar, estas alterações ocorreram pois houve necessidade de adaptação forçada fazendo com que os colaboradores passassem a trabalhar de casa (trabalho remoto) de forma repentina.

\section{PROPOSTA DE MELHORIA: MODELO}

O modelo com as sugestões de melhoria ofertadas neste capítulo traz como base os problemas identificados como insatisfatórios pelos colaboradores, e para cada item insatisfatório pretendeu-se propor uma sugestão de melhoria específica lembrando que para o plano de melhoria levou-se em consideração as respostas obtidas pelos colaboradores através do questionário.

Por mais que alguns problemas estejam correlacionados as propostas de melhoria não são necessariamente as mesmas. Obteve-se as barreiras que poderiam prejudicar cada um destes transtornos, assim como, os canais de comunicação identificados como eficazes, embora todos os canais de comunicação relatados na tabela 6 (meios de comunicação eficazes), tenham sido os melhores meios para se comunicar, não significa que todos eles possam qualificar determinado objeto insatisfatório, por isso a importância da montagem do framework para esta identificação.

Conforme identificado nos resultados, a tabela 5 informa os meios de comunicação mais utilizados e isto não significa que sejam os mais eficientes, por isso a necessidade de comparação entre as tabelas. Como exemplo, podemos dizer sobre a utilização do e-mail, embora ela tenha $100 \%$ de utilização ele possui $95 \%$ de eficácia, embora seus resultados sejam satisfatórios de acordo com o problema enfrentado ele pode não ser o melhor canal de comunicação a ser utilizado para o problema especificado, assim como, podemos citar como outro exemplo a página 
institucional, mesmo que, ela não tenha uma frequência de utilização satisfatória ainda sim é um meio de comunicação com $60 \%$ de eficácia como comprova a tabela 6 , observando que, em relação aos outros canais este foi considerado com um valor inferior de eficiência em comparação aos outros.

De acordo com o resultado do cálculo IQPS verificou-se oito problemas identificados pelos colaboradores como insuficientes e para estes problemas serão sugeridas as propostas de melhoria. Os itens considerados satisfatórios não obtiveram propostas de melhoria, uma vez que, entende-se, que estes foram bem avaliados pelos funcionários, não havendo neste momento a necessidade de propor melhorias.

Portanto, com base no conteúdo fundamental teórico, no processo metodológico e nos artigos de seus respectivos autores nesta pesquisa representados, chegou-se ao seguinte modelo de proposta de melhoria a seguir.

Figura 2 - Modelo de Proposta de Melhoria

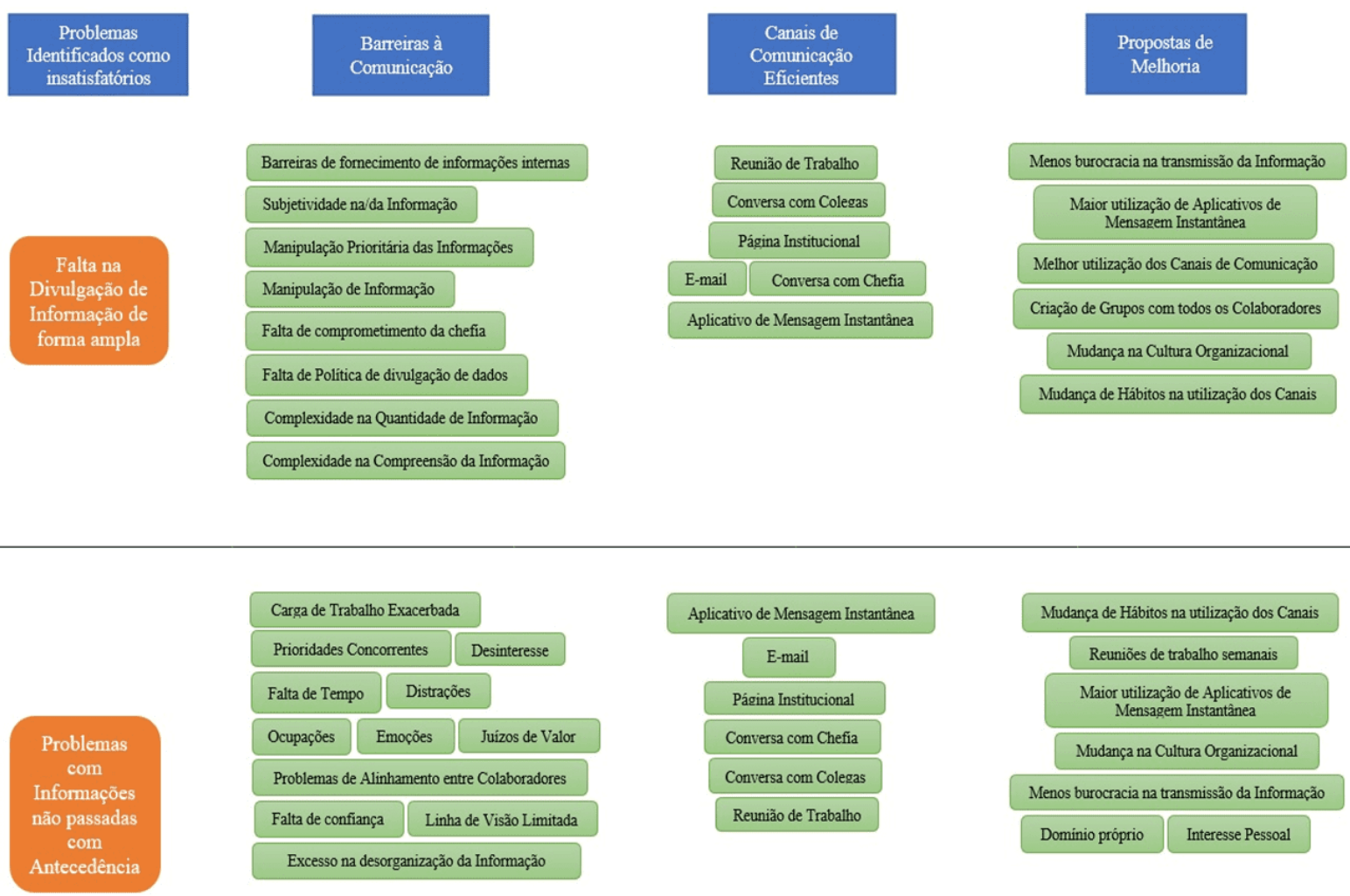

RC: 72268

Disponível em: https://www.nucleodoconhecimento.com.br/comunicacao/processo-de- 
Falta de

Conhecimento

das

Atribuições do

Departamento
Problemas de Alinhamento entre Colaboradores

Desinteresse Linha de Visão Limitada

Distrações Barreiras Psicológicas

Falta de Tempo Ocupações

Emoções Prioridades Concorrentes

Distrações

Excesso na desorganização da Informação

Carga de Trabalho Exacerbada

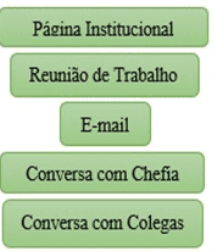

Interesse Pessoal

Mudança na Cultura Organizacional

Mudança de Hábitos para Adquirir

Conhecimento

Reunião de Trabalho

Priorizar as atribuições do Setor
Falta de

Capacitação e

Treinamento

para exercer

seu Trabalho
Problemas de Alinhamento entre Colaboradores e Chefia

Prioridades Concorrentes Desinteresse

Falta de Tempo Distrações Ocupações

Linha de Visão Limitada Falta de confiança

Carga de Trabalho Exacerbada Emoções

Estereótipos e Preconceitos
Conversa com Chefia

Conversa com Colegas

E-mail

Página Institucional

Reunião de Trabalho
Mudança de Hábitos na utilização dos Canais

Reunião de trabalho com Chefia

Mudanca de Hábito do Departamento

Mudança na Cultura Organizacional

Maior oferta de Cursos de Capacitação

Maior interação entre Colaborador e Chefía
Desinteresse Linha de Visão Limitada

Distrações Barreiras Psicológicas

Falta de Tempo Ocupações

Emoções Prioridades Concorrentes

Distrações Carga de Trabalho Exacerbada

Problemas de Alinhamento entre Colaboradores

Estilo de Comunicação por Gênero

Estereótipos e Preconceitos

Complexidade na Compreensão da Informação
Página Institucional

Reunião de Trabalho

E-mail

Conversa com Chefia

Conversa com Colegas

Aplicativo de Mensagem Instantânea
Interesse Pessoal

Melhorar relações Interpessoais

Mudança de Hábitos para Adquirir Conhecimento

Maior interação em Reunião de Trabalho

Mudança na Cultura Organizacional para acessar a Intranet

Menos burocracia na transmissão da Informação

Melhor utilização dos Canais de Comunicação

Criação de Grupos com todos os Colaboradores
Falta de

Feedback

do Trabalho

\begin{tabular}{|c|c|c|c|}
\hline \multicolumn{2}{|c|}{ Estereótipos e Preconceitos } & \multicolumn{2}{|c|}{ Emocōes } \\
\hline \multicolumn{2}{|c|}{ Prioridades Concorrentes } & \multicolumn{2}{|c|}{ Desinteresse } \\
\hline Falta de Tempo & Dist & & Ocupaçōes \\
\hline \multicolumn{2}{|c|}{ Linha de Visão Limitada } & \multicolumn{2}{|c|}{ Falta de confiança } \\
\hline \multicolumn{4}{|c|}{ Problemas de Alinhamento entre Colaboradores e Chefia } \\
\hline \multicolumn{2}{|c|}{ Barreiras Temporais } & \multicolumn{2}{|c|}{ Juizos de Valor } \\
\hline Não saber ouvir & Estil & de Co & nicação por Gênero \\
\hline
\end{tabular}

\section{Conversa com Chefia \\ Conversa com Colegas \\ E-mail \\ Reunião de Trabalho}

Aplicativo de Mensagem Instantânea

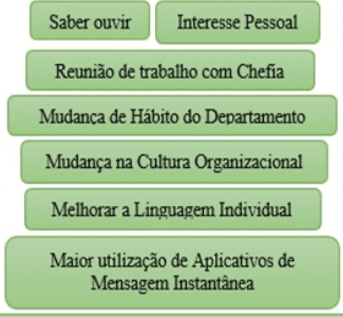

Melhorar o estilo de Comunicação por Gênero

Diminuir o Preconceito

RC: 72268

Disponível em: https://www.nucleodoconhecimento.com.br/comunicacao/processo-de- 

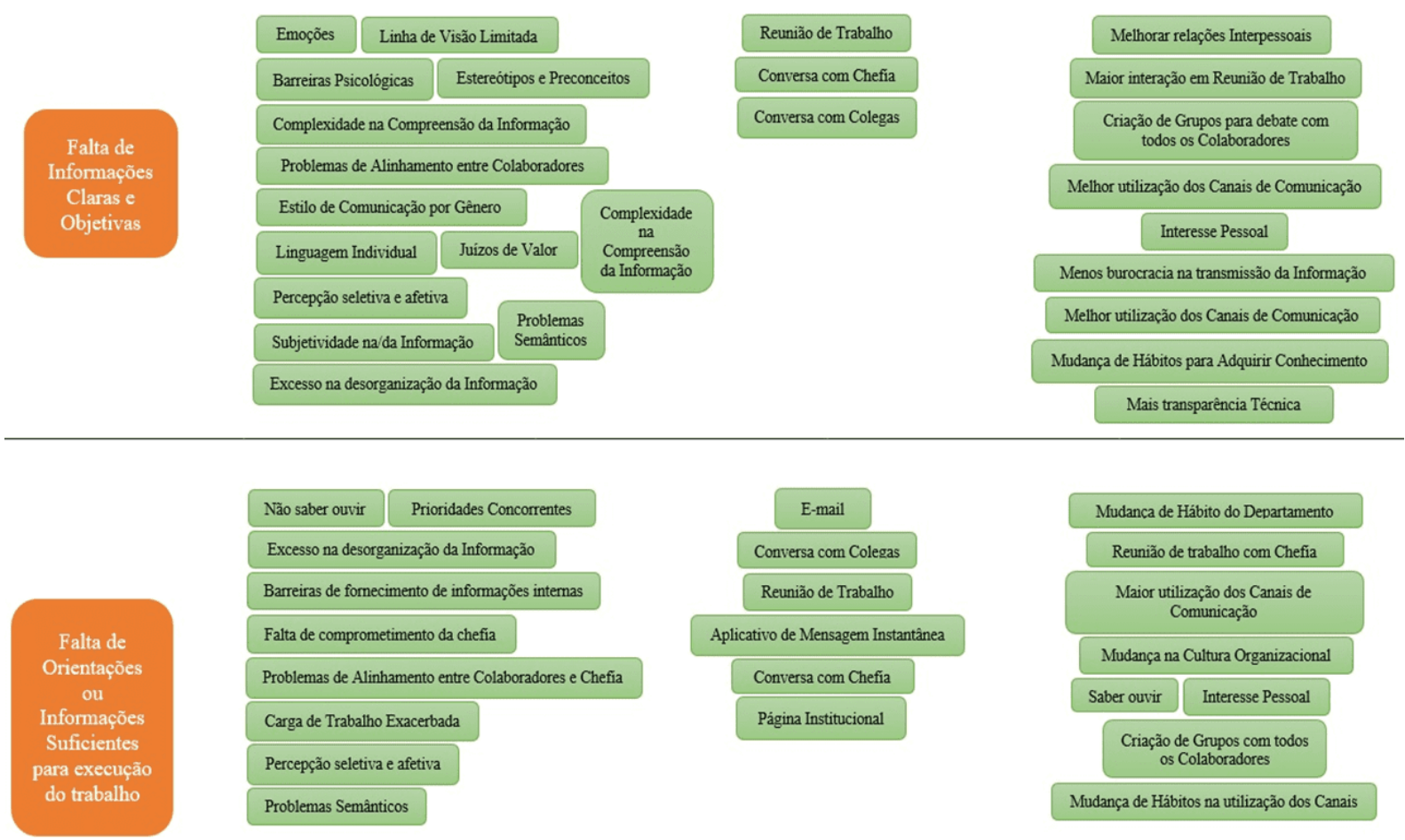

Fonte: Produzido pela autora (2020)

\section{CONSIDERAÇÕES FINAIS}

Em tempo de pandemia global a sociedade recebeu uma importante missão de isolamento social, isso fez com que alterações bruscas ocorressem para o modo de trabalhar de vários profissionais, havendo a necessidade extrema de trabalho remoto (ou trabalhar de casa). Alterações como, a forma de se comunicar, as barreiras enfrentadas no processo de comunicação organizacional, a utilização de canais de comunicação sofreram com estas modificações; assim como a cultura para utilizar estes meios de intercomunicação. Entendeu-se ainda, a importância de uma boa qualidade no processo de comunicação para todo o plano estratégico de uma Instituição Federal de Ensino.

A partir das informações obtidas nesta pesquisa verificou-se que a colaboração e a melhora na relação interpessoal da equipe transmite ao processo de comunicação outro significado, tornando-o mais satisfatório. Com a mudança de hábitos para utilizar os meios de comunicação, com a mudança na cultura organizacional, com a melhor e maior utilização dos canais, com menos burocracia na transmissão da informação,

$\mathrm{RC}: 72268$

Disponível em: https://www.nucleodoconhecimento.com.br/comunicacao/processo-decomunicacao 
com a melhor utilização da linguagem para se comunicar, pode-se chegar ao resultado esperado que os colaboradores desejam. Este trabalho, traz em si a possibilidade de ser aplicado em qualquer Instituição Federal de Ensino com o objetivo de aprimorar seu processo comunicacional interno.

Sendo assim, este trabalho atingiu seu propósito, propondo aos colaboradores deste departamento um modelo de proposta de melhoria no qual, trará excelentes resultados.

\section{REFERÊNCIAS}

ARAÚJO, C.A.Á. A pesquisa norte-americana. In:HOHLFELDT, A.; MARTINO, L.; FRANÇA, V. (Org.). Teorias da comunicação: conceitos, escolas e tendências. Petrópolis: Vozes, 2001. p.119-130.

BARBOUR, J. B., DOSHI, M. J., HERNANDEZ, L. H. (2016). Telling global public health stories: Narrative message design for issues management. Communication Research,43, 810-843.

CASALI, AM (2006). Comunicação organizacional em fusões e aquisições internacionais. Tese de doutorado não publicada, Universidade Federal Santa Catarina, Florianópolis, Brasil.

CHIAVENATO, Idalberto. Administração nos Novos Tempos. 2 ed. Rio de Janeiro: Elsevier, 2010.

COZZA, L. M.; PELOTAS, U. F. DE. Estudo Do Efeito Do Tratamento Térmico De Alívio De Tensões Na. n. November, 2019.

CURVELLO, João José Azevedo. Comunicação interna e cultura organizacional 2. ed. rev. e atual. - Brasília: Casa das Musas, 2012.

DENZIN, N. K.; LINCOLN, Y. S. O planejamento da pesquisa qualitativa - teorias e abordagens. 2. ed. Porto Alegre: Artmed, 2006. 
DUARTE, J. (s/d). Comunicação Pública. Disponível em http://www.jforni.jor.br/forni/files/ComP\%C3\%BAblicaJDuartevf.pdf. Acesso em 16 jun., 2018.

EMERENCIANO, F. L.; SILVA, É. S. DA; OLIVEIRA, J. A. DE. O Papel da Intranet na Comunicação Organizacional Interna: estudo de caso em um banco de desenvolvimento. Aedb.Br, v. 1, p. 15, 1995.

GONÇALVES, C. F. F... Qualidade do serviço da universidade pública: uma avaliação perceptiva. In: SIMPÓSIO DE ENGENHARIA DE PRODUÇÃO, 10, 2003, Bauru. Anais. Bauru: p. 1-4.

IFSP ouve comunidade interna para melhorar comunicação institucional. IFSP Câmpus São Carlos, São Paulo, 18 de jul. de 2018. Disponível em: <https://docs.google.com/forms/d/e/1FAlpQLSeoBAC5ylTsg9FFXAbKeP4U7n0otBH zSulEpQJ_OTma5DvFEA/formResponse>. Acesso em: 15 de mar. de 2020.

JOHANSSON, C., GRANDIEN, C., STRANDH, K. (2019). Roadmap for a communication maturity index for organizations-Theorizing, analyzing and developing communication value. Public Relations Review, 45(4), 101791. https://doi.org/10.1016/j.pubrev.2019.05.012

JUNIOR, Sidmar José Cruz. A Importância da Comunicação nas Instituições Públicas. Revista Científica Multidisciplinar Núcleo do Conhecimento. Ano 04, Ed. 06, Vol. 10, pp. 49-60. Junho de 2019. ISSN: 2448-0959

KUNSCH, M. M. K. (2012). As dimensões humana, instrumental e estratégica da Comunicação Organizacional: recorte de um estudo aplicado no segmento corporativo. Intercom: Revista Brasileira de Ciências Da Comunicação, 35(2), 267289. https://doi.org/10.1590/s1809-58442012000200014

LASSWELL, H. A estrutura e a função da comunicação na sociedade. In: COHN, G. (Org.) Comunicação e indústria cultural. São Paulo: T.A. Queiroz, 1987. 
LEE, Y., QUEENIE Li, J. Y. (2020). The value of internal communication in enhancing employees' health information disclosure intentions in the workplace. Public Relations Review, 46(1), 101872. https://doi.org/10.1016/j.pubrev.2019.101872

LIMA, M., \& ABBUD, M. (2015). Comunicação Organizacional: Histórico, Conceitos e Dimensões. Atas da Intercom - Sociedade Brasileira de Estudos Interdisciplinares da Comunicação XIV Congresso de Ciências da Comunicação na Região Norte, Manaus. Retirado de www.portalintercom.org.br/anais/norte2015/resumos/R44 -0415 -1.pdf.

MOMO, F. DA S. et al. Gestão do conhecimento na área de sistemas de informações: Uma revisão no contexto brasileiro. Perspectivas em Gestão \& Conhecimento, v. 9, n. 1, p. 138-153, 2019.

MOREIRA, Aline de Oliveira. MOREIRA, Michel de Oliveira. A Comunicação como um Direito Humano. Revista Científica Multidisciplinar Núcleo do Conhecimento. Ano 05, Ed. 06, Vol. 04, pp. 17-35. Junho de 2020. ISSN: 2448-0959, Link de acesso: https://www.nucleodoconhecimento.com.br/comunicacao/direito-humano

NEVES, F. T.; DENARDI, T. C. Issn: 2176-171x. p. 6-18, 2019.

NOBILE, J. et al. Organizational communication and occupational stress in Australian catholic primary schools. Journal of Educational Administration, [S.I], v. 51, n. 6, p. 744-767, 2013.

OLIVEIRA, L. J. et al. Qualidade, Satisfação e Comprometimento: Um Estudo nas Relações BtoB na Indústria de Eletricidade. Revista de Ciências da Administração, p. 80-103, 2008.

OLIVEIRA, Maria Helena Cozzolino de. Metodologia da Linguagem. 7.ed. São Paulo: Saraiva, 2007. 
PERSPECTIVA, N. A., et. al. (2007). A Comunicação Interna Na UFP. A comunicação interna na UFP na perspectiva do QUESCI. Disponível em: $<$ https://bdigital.ufp.pt/bitstream/10284/1040/3/questionario.pdf>. Acesso em: 13 de fev. de 2020.

PIZZAIA, Â. et al. O papel da comunicação na Gestão do Conhecimento: aspectos relevantes e estímulo a novas pesquisas. Pesquisa Brasileira em Ciência da Informação e Biblioteconomia, v. 14, n. 1, p. 62-81, 2019.

RISCHBIETER, S. (2015). Comunicação e cultura organizacional: o caso da Meu Móvel de Madeira. 122.

ROBBINS, S. P. Fundamentos do Comportamento Organizacional. São Paulo: Prentice Hall, 2004.

SCHERMERHORN JR, John R.; HUNT, James G.; OSBORN, Richard N. Managing Organizational Behavior. 5. ed. USA: John Wiley \& Sons, 1994.

SOARES, W. S.; CUNHA, N. C. A influência das redes sociais nas empresas. Revista GETEC Gestão Tecnologia e Ciências, v. 6, n. 14, p. 56-73, 2017.

TURBAN, E.; McLEAN, E.; WETHERBE, J. Tecnologia de informação para gestão: transformando negócios na economia digital. 3. ed. Porto Alegre; Bookman, 2004.

ZHAO, X., ZHAN, M., JIE, C. (2018). Examining multiplicity and dynamics of publics'crisis narratives with large-scale Twitter data. Public Relations Review, 44, 619-632.

Enviado: Dezembro, 2020.

Aprovado: Janeiro, 2021. 